\title{
Chapter 19 \\ Identify, Search and Monitor by Tracks: Elements of Analysis of Pastoral Know-How in Saharan-Sahelian Societies
}

\section{Laurent Gagnol}

\begin{abstract}
This article deals with the knowledge and skills related to tracks in the sand among nomadic and semi-nomadic populations with a predominantly pastoral focus in the Sahara and Sahel. Identifying a sought-after individual, interpreting the associated clues, catching up with it by following the trail - all this is an essentially pastoral know-how. The punctual examination of the footprint aims at identifying the individual who produced it, and the search for clues associated with the footprint enables the tracker to discern other elements interpreting more generally the behaviour of this individual in movement. Through the understanding of the spatial and temporal context, linear tracking of footprints, by implementing a hodological strategy, makes it possible to catch up with the individual in question. Furthermore, this chapter discusses the power structures between the men who are in charge of tracking as well as the confirmation, assurance or subversion of the social order it implies. Finally, the permanence and transformation of this common and essential know-how in the process of becoming sedentary are analysed.
\end{abstract}

Keywords Track $\cdot$ Footprint $\cdot$ Path $\cdot$ Nomadism $\cdot$ Pastoralism $\cdot$ Hodology $\cdot$ Sahara

\section{Introduction}

Kel Awal a énnan: wa éshewayan tareyt wer gé élis ("The people of the word say: he who follows the path is not a man.”)

This proverb of the Tuareg Kel Ewey of Niger highlights the deeply rooted idea that an accomplished man never gets lost and should not passively follow a path: he makes his own way by examining the multiple traces on the ground. Unlike their sedentary neighbours, these nomads make it a point of honour not to depend on a route: depending on the objectives and circumstances, they examine ephemeral and

\footnotetext{
L. Gagnol $(\bowtie)$

EA 2468 Discontinuities, University of Artois, Arras, France

e-mail: laurent.gagnol@univ-artois.fr
} 
discontinuous tracks that they follow or they choose to deviate from it. Consulting the tracks is not only about trying to orientate oneself and to find the way in the desert; it is also about interpreting the life that takes place there with all the movements, gestures, intentions, sensations, unexpected events that occur along the way as well as unexpected detours and subsequent narratives. Nomadic travel is not reducible to a journey between two points. It is to inscribe in the sand its passage within a network of itineraries of individuals who are also confronted with the desert environment and its traces.

This chapter presents the results of an empirical study on the knowledge and skills related to tracks in the sand among nomadic and semi-nomadic populations with a predominantly pastoral economy in the Sahara and Sahel. More precisely, they are the result of a thesis research among the Kel Ewey Tuaregs of Aïr in northern Niger (Gagnol 2009), exploratory surveys conducted in northern Chad (in January/ February 2013) and especially in central Niger (in July/August 2012). While some additional observations are made, thanks to a short study carried out among the Tubus of Chad - more precisely the Daza and Bideyat of Borku and Ennedi - this study is essentially based on the analysis of about 15 in-depth interviews (individual and collective) with semi-nomadic agro-pastoralists of the Kel Agalal tribe (who belong to the Kel Gress Tuaregs) and who live part of the year in the community of Tajaé, south of the city of Tahoua in Niger. Most of the people interviewed are recognized as specialists, and most of them are elderly men, having lived as nomadic or semi-nomadic pastoralists, caravan guides and/or transhumant herders, providing them with a long experience in camel-dominated breeding. They have a high level of expertise in footprint inspection and tracking, and their wisdom is sometimes called upon to solve difficult cases.

This chapter follows a theoretical and epistemological construction on tracks that is relatively ancient - notably the evidential paradigm of Ginzburg $(1980,1989)$ and Ingold $(2004,2007)$ but lacks empirical study. Remaining as close as possible to its materiality - by an approach elsewhere qualified as geoichnological (Gagnol et al. 2018), a track is considered here as the material result of the passage of a moving body. It is ephemeral (being preserved and fossilized only on very rare occasions), specific (since it depends on the nature of the medium and many other circumstances) and individualized (since it identifies a single individual). Beyond the only specialists we were able to interview, the knowledge on the tracks is widely shared by all the Saharan and Sahelian rural populations and is part of a common and essential daily know-how (especially for pastoral and hunting activities). The similarity of the data collected between northern Niger and Chad attests to this. However, with a few exceptions (e.g. Liebenberg 1990; Therrien 1990; Aporta 2004), the lack of scientific literature on the subject does not allow this hypothesis to be confirmed and generalized to all pastoral and/or nomadic societies in the world. Other methods complementary to those presented here must be considered (see Lye Chap. 18) to deepen the knowledge (and their mode of transmission) that this knowhow implies regarding tracks. This could involve investigating in situations through practices and not only through speech. 
After having presented the unexpected richness of the know-how mobilized in the examination and tracking of spoor, the question of the power structures it implies will be raised and finally the question of the permanencies and current transformations it is experiencing under the effects of sedentarization.

\section{Inspect, Interpret and Follow Tracks: A Common and Essential Activity in the Sahara and Sahel}

\section{Geographical Knowledge Relating to Sandy Soil}

Pastoral societies such as the Tuaregs have a very rich geographical vocabulary to designate the diverse nature of the soils they travel and inhabit. Two generic terms are associated with the idea of soil: that of akal referring to the English notion of territory, country or region, without presuming any legal dimension (the territorial sovereignty) as a precise delimitation or scale, while the term amadal refers to the soil as a support and spatial extent (the terrestrial surface). It also refers to the soil in its materiality and depth (the earth, the underground world and the different aspects of the soil considered from the point of view of its composition). The Tuaregs distinguish precisely between different types of soil according to their texture but also according to whether or not they are suitable for footprints. For example, taghardé refers to a hard lateritic soil where it is impossible to follow the tracks. As for the word ézizel, it has a prototypal value. It is the noble sand of the minor bed of the wadis that offers the best qualities for the multiple practical and aesthetic functions that are attached to it. It is considered soft, white and pure because it is not dirty. Being sterile and mobile, it embodies positive values as opposed to the entrenchment of agrarian societies that identify with fertile humus.

The wadi bed arena is the most widely used material and has recently even become a small business. It is not necessary here to list the uses of sand in daily life or at specific events. Let us limit ourselves to noting its omnipresence: if it covers a large surface area of desert expanses and is thus attributed a wild character, it is also present within domestic spaces. Ezizel sand is brought and deposited inside abodes (tents, houses, mosques, etc.) and on the ground just in front of their entrances (the same applies among the Tubus). The interior walls are covered with it to make them smoother. ${ }^{1}$ In general, sand is used almost daily: it is used as a writing medium (tifinagh alphabet, drawing, cartography, geomancy, etc.), as a mnemonic during an enumeration or simply to punctuate an argument or the salient features of a story. It is a mechanical gesture, and it is not uncommon to draw lines to pass the time while participating in a collective discussion, and which is immediately erased by sweeping it away with the hand. The games played in the Sahara are also based directly on

\footnotetext{
${ }^{1}$ The rest of the houses are built with bricks made of a mixture of clay, sand and sometimes straw, all dried in the sun (adobe, known as banco in the Sahel).
} 
the sand ${ }^{2}$; it is also used for culinary preparations (based on grilled meat or the famous breads baked in the sand and ashes, togella) and as a cache (provisions of food and water but also weapons). It is additionally used for dry ablutions and for therapeutic use (hot sand massage or heated tégharghart to treat cold diseases, or by using termite mound sand, considered to be sheltered from geniuses). However, sand can make you sick: direct contact with hot sand can cause a specific pathology ézez, same as damp and cold sand, tessemdé. There are also hunting and warfare techniques specific to the dune environments that the nomads master.

Finally, sand has a ritual value: while it is known as belonging to the wild world, that of the bush dominated by geniuses, ${ }^{3}$ the floor of domestic spaces is covered with it at each rite that marks social life. ${ }^{4}$ Sand is thus at the heart of the domestic world. ${ }^{5}$ This is not without risk: for example, the tracks of newborns crawling on all fours on the sand would be erased for fear of being licked by geniuses, leaving them unable to walk. In some practices of black éshaghaw magic, sand is used to cast a curse on someone, preferably taken from the tracks left by the person's bare foot. ${ }^{6}$ There are also sand-based prophylactic procedures to make rain and wadi flow and to stop an epidemic or a conflict (Gagnol 2009: 461-462).

Finally, drawing a line in the sand was of particular importance to the Tubus. One practice which seems to have disappeared today attests to this: it is a ground marking called ortozze. ${ }^{7}$ At meetings of elders convened to settle a dispute, a line was drawn to separate the opposing sides: the fine was cancelled or doubled if one of the persons of the complaining party or the other crossed it. Other cases of ortozze imply a circle that was drawn around a date palm tree whose dates were beginning to ripen, which was how the owner was giving a warning signal to potential thieves. An even more serious warning is to draw a line on one's own trail when one knows one is being followed which is to indicate to one's pursuers that a weapon will be used if they continue beyond it, hence the trail becoming the path of war. Moreover, warning these enemies with this signal makes it possible to be absolved in the event of a deadly confrontation.

\footnotetext{
${ }^{2}$ On the issue of sand in Tuareg games, see, for example, Bellin (1963) and Casajus (1988).

${ }^{3}$ The "song of the dunes" describes sand as an element of the geniuses, the whirlwinds being their caravans.

${ }^{4}$ In particular childbirth, appointment and wedding ceremonies, as well as religious holidays

${ }^{5}$ For example, the legendary account of the destruction of the Tuareg village of Takawat (Aïr, Niger) by a whirlwind of sand refers to the disorders created by a symbolic inversion between wild and domestic during a lavish wedding: to constitute the bridal tent, instead of sand, millet was placed on the ground; instead of leaflet mats of palm trees, fabrics were preferred to constitute the velum; instead of water, honey was poured into the jars; instead of a bull, it was a slave who was sacrificed (Gagnol 2009: 401-404). Among the Teda Tubus of Tibesti, the opening of the wild grass harvest in each valley gave rise to alms: a fragrant plant was thrown into the sandy bed of the wadi (Chapelle 1982: 382).

${ }^{6}$ This practice is very widespread: Lévy-Bruhl gave some examples on three continents (1927: 72-73).

${ }^{7}$ On this subject, see Le Cœur 1950: 160; Chapelle 1982: 320, 330, 334.
} 


\section{A Shared but Unevenly Distributed Pastoral Know-How}

A Tuareg riddle asks: "They are everywhere but you can't grasp them. What is it?" Answer: "The tracks."

The Tuareg language is very rich in vocabulary associated with spoor. There are more than a dozen terms to name the different types of trackways and paths. Concerning more precisely the tracks, there are about ten words: the generic term is adériz, while tekkelt refers to the human footprint, asemmejannu the footprint of a crouching animal, azeggelleliz a footprint in agitated sand, etc. At least seven verbs refer to the act of following a track and to subtle differences that are difficult to distinguish. The verb agararas means, for example, "to follow the tracks in the opposite direction".

Tuareg and Tubu pastoralists recognize each of the animals they own by their footprints. The identification is thus individual. It applies to dromedaries, cows, donkeys and horses as well as to goats, but not to all sheep. ${ }^{8}$ Frequently, they also know how to identify each head of cattle in the surrounding camps or concessions near the village. Finally, they recognize the footprints of the people of their camp and the surrounding camps and, among the sedentary groups, of some and sometimes all the people of the village. People know when they are dealing with foreign tracks, both for humans (they immediately recognize the arrival of a stranger) and for domestic animals (these are lost or stolen animals), or even for wild animals, as we will see later. The familiarity of the place and the intimacy with the people are thus lived through the tracks.

Footprint identification is an unevenly distributed capacity. It depends on the more or less great experience, the sense of observation and attention given, but also on the intelligence and memory of everyone: some people, it is said, recognize by the imprint the return to the village of a caravan or a migrant (called exodants in the Sahel) who left several months earlier. Specialists are sometimes called upon to solve difficult cases. They are mainly responsible for identifying the footprint and then indicating the track to follow, going up a few tens or hundreds of meters. They are not paid for it. Specialists can recognize the track of a lost animal that has crossed, or remained with, another herd (and animals are often lost because they follow another herd). In search of a dromedary, it is not uncommon to follow tracks over 2 or 3 days. ${ }^{9}$ Some pastoralists who are unfit to identify their animals with their

\footnotetext{
${ }^{8}$ Identifying ewe and ram by their footprints is less easy anatomically (their feet are very similar) and ethologically since, as gregarious animals with less marked individuality, it is more difficult to differentiate them by their behaviour: moreover, some individuals do not have an assigned name. Ewes are considered less intelligent and cunning than most animals, especially goats (on domestication among the Tuaregs, see S. Cabalion's thesis 2013).

${ }^{9} \mathrm{Up}$ to 1 week for exceptional cases. It is said in Tajaé that a man was able to follow the tracks of his guinea fowl for $5 \mathrm{~km}$ before finding them. Another found his lost sheep in the middle of a herd of about a hundred heads, etc.
} 
footprints would tie wire under their hooves to facilitate their task. But this technique, rare and hidden, seems very uncommon because of the mockery it causes.

\section{Footprint Identification Criteria}

When examining the imprint, it is the anatomy of the foot that is analysed in the depression. Tracks enable to detect the anatomical characteristics of each individual's foot. In the case of the foot of dromedaries, Saharan pastoralists examine the sizes, volumes and wear of the constituent parts, namely, the sole, the heel, the two toes and their nails, the central slit, cracks and other features (Figs. 19.1 and 19.2). Each dromedary has a unique gait that the inspection of the print reveals: some project a little sand that settles next to the print; others press more uniformly without making a projection. For goats, sheep and cows (Fig. 19.3), it is mainly the shape of the hoof hooks and their possible crossing that distinguish them. The contact to the ground also differs: some only wear out that part of the hoof that touches the ground. It is also noted if the animal drags the hooves (Fig. 19.3). The same is true for humans: each has a characteristic foot shape and prop that are imprinted in the sand. The track depends on the anatomy of the foot but also on the gait. Part of the foot can touch the sand: some press more on the heel, others on the tip and others on the outer or inner edge. It also depends on the opening angle of the feet ("duck feet" or with an inward angle). Finally the pace is a distinctive criterion: the length of the step and the type of stride (trampling, shuffling, etc.). All this is observed through the

Fig. 19.1 Footprint of a dromedary's front and rear foot (Eghazer, Niger). This is a relatively recent imprint, but the wind has already blown in twigs. There are traces of urine droplets. The dromedary walks in an amble: this symmetrical, two-step pace means that the imprints of the anterior and posterior legs on each side are alternately brought closer together (here, they partially overlap). (Photo A. Afane 2013)

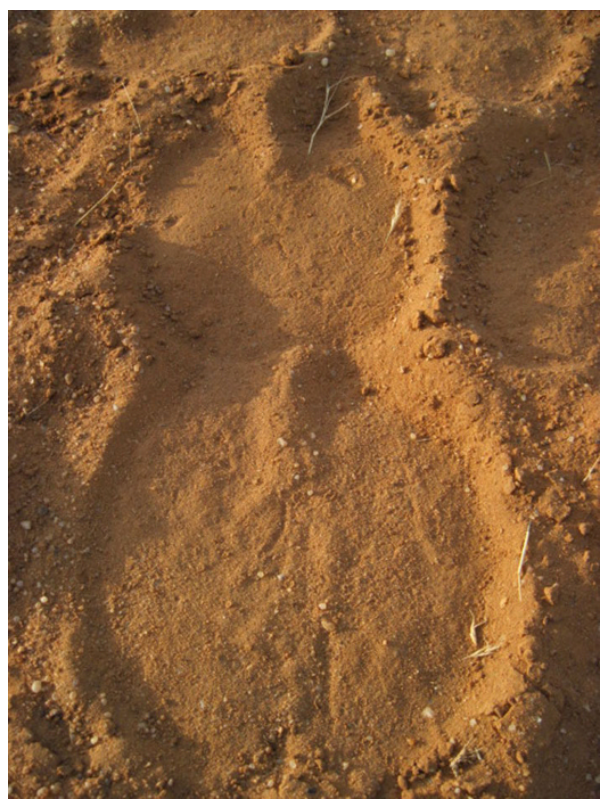


Fig. 19.2 Imprint of a dromedary (Eghazer, Niger). Recent footprint but tracks of nocturnal insects that intersect it indicate that it dates from the previous day. (Photo A. Afane 2012)

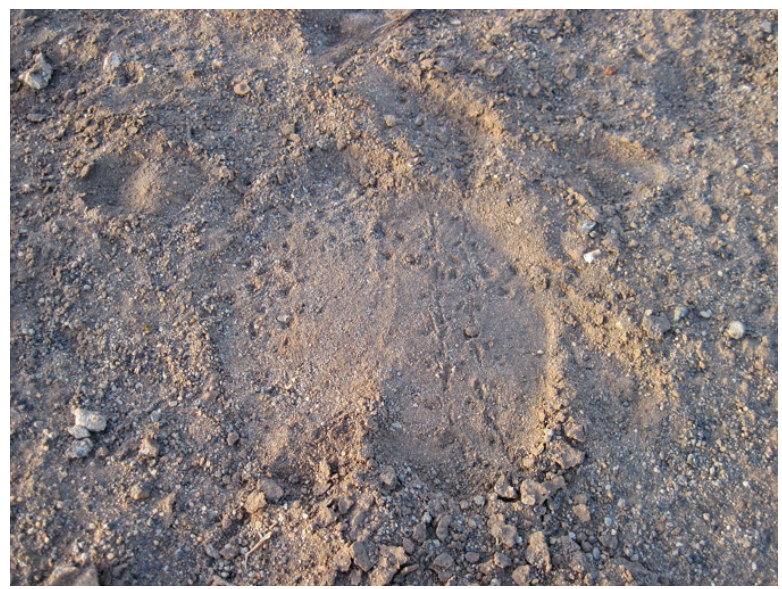

Fig. 19.3 Cow track (Eghazer, Niger) This heifer has the particularity of dragging its legs as shown by the small features that extend the footprints. (Photo A. Afane 2012)

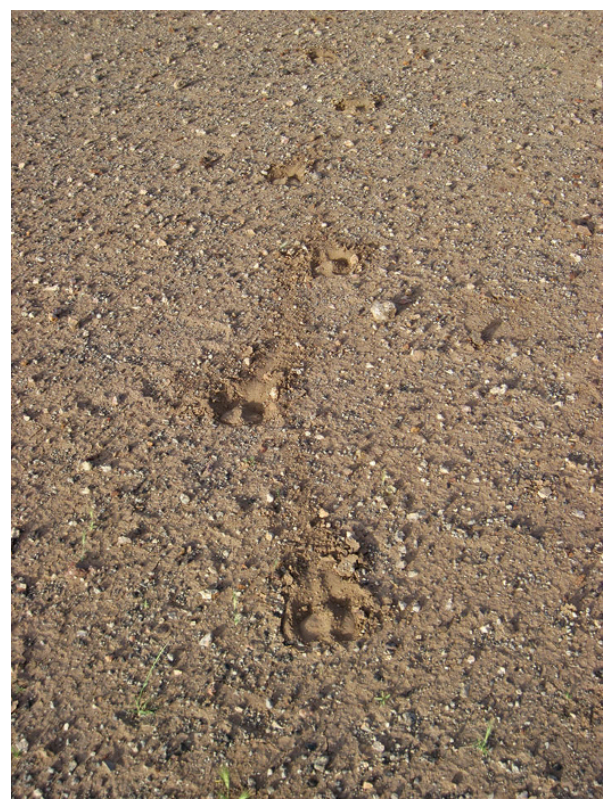

differentiated wear of the sandals that are printed in the sand and allows individual identification.

Track inspection reveals certain particular characteristics that are specific to the individuals who left them. In the case of the dromedary, a herder can deduct from the print its approximate age. Moreover, the Tuaregs determine age according to the growth of teeth and the size of footprints rather than by size. It is easy to distinguish the first years according to the growth of the foot. But, from the seventh year onwards, when growth stops, it becomes more difficult. The appearance of the tracks (and what it indicates about behaviour) also reveals the animal's age: the 
juveniles are turbulent and jostle each other, while the older ones are quiet. For cows and goats, age determination is more approximate: the older they are, the more they drag their feet, and the hooks/nails are longer. The sex of the dromedary is revealed by the size of the sole as well as by the length of the step (and therefore the distance between the prints). In addition, the female dromedary's footprint is deeper (especially when dealing with a fully grown female), and the urine traces are different. The examination of the prints also reveals the unusual depth associated with a load (for a donkey, a bottle filled with water; for a dromedary, luggage such as that of caravan guides, etc.). Another indication is that when an animal carries a weight, the step length is shorter. When an animal is mounted, it can be recognized by the depth of the track but also by the more linear direction of travel. Trackers can distinguish certain diseases of the animal (the dromedary scratches its back with its legs or rubs against a tree for example), and they also see the degree of fatigue and injuries (limping, bleeding, etc.). The length of the steps and the degree of sinking of the feet increase with the speed of the animal: they allow detecting a slow or fast walk, a trot or a gallop, which is useful if one tries to evaluate the time it will take to reach the individual being followed by its tracks. Because we can, as we will see later on, determine quite precisely when the passage of the individual who left his track had been.

\section{Hodological Strategy and Temporalities of Tracks}

Footprint inspection allows to identify the animal and to know its path, i.e. the direction it has taken. But if someone wants to track spoor and track the individual who produced it, a one-time examination alone is not enough. Because following tracks is sometimes counterproductive, it wastes valuable time when looking for a lost animal that makes detours (or a thief who tries to make the tracks disappear or blur them). Besides, a track is not just a series of rectilinear imprints. The path it forms is very sinuous, and the line is often broken (by the temporary absence of tracks). That is why in order to follow an animal or a human Saharans, apply what could be called a hodological strategy.

The neologism hodology (or odology, from the Greek hodos, the path, the way) is a term used in psychology at the beginning of the twentieth century, referring to the notion of subjective space (Besse 2004). We refer to the work of the historian of ancient geography P. Janni (1984). Through the geographical narratives he analyses, Janni sees an opposition at work between a cartographic vision of the world (two-dimensional according to the axes of geographical coordinates) and a linear and multi-dimensional perception of the world, within which the time of travel, but also the movement and direction taken by journeying (real or fictional), takes precedence over the orientation according to the cardinal points. In some ancient texts, places or regions are described one after the other according to an itinerary, and everything happens as if the story shows a perception in situation and in movement. The surfaces and boundaries that prevail in the cartographic representation of the 
world are secondary in the hodological understanding of space, which is above all linear and mobile. ${ }^{10}$

The hodological strategy in spoor tracking consists in disregarding at least temporarily the punctual footprints by cutting the supposed itinerary formed by them, in order to meet the individual by a more direct and linear path. This is what the Tuareg verb elked means. The objective is then to join the trackway further forward where to find newer prints, while the challenge is to reach the individual without going beyond it. In practice, therefore, following punctual footprints is not all and everything. A tracker imagines the general path, the supposed purpose of the animal or human and the means or stratagems he or she will use to achieve it (so he must adopt their point of view and put himself in the perspective of others). This implies knowing not only the behaviour of the individual in question and even his or her character but also the places where he or she resides. It is all these skills that will allow to do less distance and therefore save time in order to catch up as quickly as possible (e.g. by going directly to a well). Following the tracks is a spatial game, a hodological one precisely speaking, because it is linear and in motion, but it is also a temporal game. To be effective, a tracker must project himself simultaneously in space and time. Doing it as quickly and directly as possible thus amounts to project oneself into the future and not only to follow the footprints, the traces of the past. ${ }^{11}$

The tracks suggest a passage, a movement: this implies for the tracker a distance to be covered, a speed and a time to complete it. In order to evaluate the distance remaining to reach the desired person, the tracker must calculate approximately that person's speed (the pace of walking) and thus the duration of his journey (the time between them). Then, by choosing a more direct route to retrieve the tracks, he must follow a particular course. After covering the estimated distance in a straight line, the route he has followed will become an area to inspect for fresh tracks.

Following a trackway is thus paradoxical from a temporal point of view: it is necessary to interpret past actions by what remains of them while being prospective. For the present of the tracker is the past of the being he seeks; the present of the latter being the future of the former. Following tracks is both going back in time and starting a countdown. Because time is precious, it is important to avoid that the animal goes too far and that the tracks are erased. It is crucial to know how to locate the footprint over time. Here again, the know-how is precise. New tracks are characterized by the fact that they have not been disturbed by the wind and that they have not been crossed by nocturnal insects. Saharan pastoralists distinguish

\footnotetext{
${ }^{10}$ These two visions are most often intertwined, and it is not a question of systematically opposing them. In the spatial practice of Saharan nomads, a hodological vision coexists with a cartographic dimension and an orientation according to the four cardinal points. On this subject among the Tuaregs, see the analyses of Bernus (1981 and 1995), D. Casajus (2010) and those of my thesis (Gagnol 2009).

${ }^{11}$ We disagree here with Ginzburg's (1980) analysis which opposes the hunting "deciphering" turned towards the past to the divination, turned towards the future. As we have indicated, the intellectual operations involved in the tracking of traces (pastoral as well as hunting) also have a prospective aim.
} 
Table 19.1 Objectives and means of know-how on tracks

\begin{tabular}{l|l}
\hline Objectives & Means \\
\hline Identify the individual & Imprint inspection: ad hoc review \\
\hline Tracking to catch the individual & $\begin{array}{l}\text { Tracking the trackway with a hodological } \\
\text { strategy: linear examination }\end{array}$ \\
\hline $\begin{array}{l}\text { Discern its behaviour and the spatial and temporal } \\
\text { context (of its passage and path since then) }\end{array}$ & $\begin{array}{l}\text { Search and interpretation of associated } \\
\text { clues: ethological and territorial examination }\end{array}$ \\
\hline
\end{tabular}

between the footprint that has a few hours (half-day), the one that has a day and the one that has spent a night. They can estimate the number of nights up to ten sometimes. Beyond that, the tracks are completely erased even if their disappearance depends on the substrate and especially on the meteorology (wind, rain, etc.).

\section{The Clues Associated with the Tracks}

The punctual and linear examination of the track is associated with the observation and interpretation of other clues that could facilitate the identification or search for the individual (Table 19.1).

An animal is identified by its imprint but also visually by its coat, by its branding mark $^{12}$ and even by its appearance when observed from a distance. Among the sensory qualities that are used, visual perception dominates. However, hearing is essential: people recognize, it is said, each species but also each individual by its call (cf. Lye Chap. 18). Smell and touch play less a role except, for example, in the examination of droppings. Complementary to the footprints, the latter are analysed in detail because they provide information on the time elapsed since the animal passed through due to their degree of humidity, crumbling, etc. Clues left punctually such as a trace of urine, a blood stain, a remnant of hair hanging on a thorny bush or lying in the print, a broken or browsed branch, a lair or a wallow - they all provide additional information. Dromedaries, for example, like to wallow in the sand and make a bedding by which one can see if they have spent the night there.

In addition to specific clues, a good knowledge of the territory is essential: it is necessary to know the water points and the good pastures to anticipate the direction taken by the animal. This familiarity with the territory is complementary to an intimate knowledge of animal behaviour. The ethological knowledge of pastoralists is based on ecological knowledge at the species level, but also on the habits specific to each animal on the scale of individual preferences. For example, herders know the

\footnotetext{
${ }^{12}$ Some branding marks of cattle among the Tuaregs and Tubus are animal tracks (raven, bustard, gazelle, snake, etc.). These property marks are not individual but represent clans or fractions of tribes. They are not necessary for the identification of the animal but above all make it possible to prove the possible theft for vis-à-vis a third party. On this issue, see Landais (2000).
} 
preferred places for dromedaries ${ }^{13}$ which get lost by rushing towards or lingering near salt springs, or for some individuals which favour specific feeding areas (such an animal likes to enter millet fields and causes damage). Knowledge of individual habits makes it easier to find animals. For example, some breeding animals tend to chase females, so it is sufficient to identify the camel mares herd. Moreover, from the animal's imprint, one can infer its behaviour: it is discernible that a goat likes caprioles and that a camel is lazy, while another camel is irresolute.

If the track is lost and there are not enough clues, one can still be put on the trail by asking people who are met on the way for information. Because pastoralists know if there are any tracks of foreign animals on their rangelands. To increase the chance of finding an animal, one can also use divinatory procedures, votive offerings and religious alms (takoté among the Tuaregs, sadaga among the Tubus).

\section{Confirm, Secure or Subvert the Social Order}

\section{Tracks as a Reflection of the Social Hierarchy}

Through footprints, pastoralists recognize the different animal species but also intraspecific "races". The Kel Gress Tuaregs distinguish two main races of camels: the bicoloured ones, whose sole is rounder with a more pronounced slit (the azelghaf race considered more intelligent and robust, but less aesthetic and with poor eyesight), and the preferred saddle race (ejiwi more slender with a cream-colored plain coat), whose footprint is smaller with a smoother and longer sole. The Isherrifan Tuaregs, considered as specialists in tracks in the Airr, go so far as to differentiate two races of sheep from their footprints. The origin of animals is also known according to the terrain they frequent: the dromedaries of the Air or Tibesti have a rougher sole, being adapted to rough and rocky soils, unlike the softer and more elastic sole of camels in the depressions and valleys of the Azawagh, Bourkou or Ounianga, which are used to sandy soils.

Contrary to the know-how on the tracks, linked to experience and personal intelligence, the gait and thus the imprint may be transmitted in a hereditary way. For Saharan pastoralists, anatomical features and the way of walking are transmitted from parents to children, and this can be seen in the tracks. As a father walks, so walks the son; or among the matrilineal Tuareg of the Aïr, rather like a maternal uncle so walks the nephew. But also a young dromedary walks like its mother. For

\footnotetext{
${ }^{13}$ If not, there are other possibilities to detect them: at least that is what most stories of the discovery of springs, ponds, palm groves and salt marshes tell us which were found by following the tracks of a lost animal. For example, in Ennedi, it is claimed that it is by noticing the wet goatee of one of their goats and following its tracks that the Sara (Bideyat clan) discovered the Fada pond (guelta) and made it their home territory. In the same way, the Kel Ewey Tuaregs explain that it is by following the tracks of a lost camel that they became aware of Bilma's salt and palm groves, which they have since travelled in their caravan cycle.
} 
example, it is told in Tajaé that a caravan guide had lost his dromedary more than a year ago. When he examined the tracks of a young dromedary, he knew that they were those of the offspring his female camel had had in the meantime. He followed the young dromedary's tracks that led him directly to the mother.

Similarly, in human beings, internal differentiations can be recognized - but more difficultly - through footprints. Ethnic groups have few detectable anatomical features. Rather, it is the cultural habits of each ethnic group that are revealed through the tracks. The Peuls Wodaabe of Niger, e.g. walk a lot and as a result, it is said, have toes spread apart. In addition they often use a stick which is clearly visible on the ground. In the same way, the Tubus say that people in Ouaddai or southern Chad have different footprints from their own even if with today's intermarriages the differences are less clear-cut.

The hierarchical organization internal to pastoral societies is said to be more clearly identifiable by the tracks: each social category has a particular imprint. According to the noble Tuareg interlocutors, this is due to the fact that a man from this amajagh provenance has a haughty appearance (called takama) that can be observed in the imprint. He walks with a slow and steady pace, pressing firmly on the ground with the head held high, his back straight and his arms coordinated with the walk. This makes the feet stand out clearly in the imprint which is well marked and harmonious. There is no sand projection or dust raised. In contrast, the despised caste of the inadan artisans/smiths would, according to these same interlocutors, have an uneven gait made up of small quick steps and a disordered pace: the chest is advanced and the arms swing negligently behind the body. The prints are uneven and poorly formed. This appearance, considered as a buffoon by the higher categories, is called taweligwelig. It also corresponds to the appearance of former slaves who would trot in a disordered way. The track translates the body techniques and social order they reflect.

For dromedaries, trackers find this hierarchy in the gait and in the imprint: those with a saddle walk calmly, harmoniously and orderly, while those named azelghaf which are used for the gear of caravans sting the ground and hop. The look is more unattractive which is reflected in the appearance of the tracks.

\section{How Can You Steal Without Signing Your Crime in the Sand?}

After the search for lost animals or animals left unattended on pasture (dromedaries in particular), one of the first functions of the know-how on the tracks consists in finding a stolen animal by identifying and tracking it and then finding its thief by the signs he leaves on the sand. ${ }^{14}$ Thieves are often strangers, so they are very easy to be

\footnotetext{
${ }^{14}$ It also happens that someone goes in search of an individual which has got lost or has gone "crazy" and is lost in the bush. It is also possible to catch up with a travelling companion or a caravan that left early, etc.
} 
recognized by their footprints in a nearby camp. Moreover, if theft is not considered to be committed by relatives or allies, it can take on a more rewarding aspect if it is committed by tribes towards whom a relationship of rivalry or even hostility persists. Among the Tubus in particular, cattle theft was once a mandatory step in proving one's bravery and ability to be an accomplished man. But today pastoral tribes are mainly victims of theft by sedentary populations when they are on transhumance during the dry season in the southern Sahelian regions. Caravan guides in particular are therefore very attentive to the footprints of their animals but also to those of neighbouring camps in order to react quickly in the event of loss or theft, the former often turning into the latter in these more populated regions that they know less well.

There are reliable clues to identify that an animal is stolen: the direction it takes is straight, and its footprint is deeper as it is mounted. If the thief walks, one can see his footprints next to the animal: either in front, and in this case he pulls it by the lanyard, or behind to move the animal forward which can be hobbled (in this case, pursuers can locate the place where the trammel was removed). Once a robbery has been detected, the victims try to find the thief by his tracks. The flight can be confirmed during the chase by observing the traces of camps where they stopped or loaded the animal into a vehicle. The pursuit may extend over tens or even hundreds of kilometres and cross international borders. It is not uncommon for Chadian Ennedi pastoralists to pick up their dromedaries from livestock markets in Darfur, Sudan, or for Tuaregs from Nigér to travel as far as Nigeria or Chad.

The thieves obviously know that the victims will be on their trail. They have schemes to scare them off and cover their tracks. They make detours, pass over hard soils (dry clay, rocks) or high grass and avoid sandy areas. If they cannot outpace those who are after them, they can waste their time. The objective for them is not to discreetly slaughter the animal which would delay and block them, but rather to bring it to the market to sell it alive. Some thieves even attach a small piece of cloth to the hoof (or a blanket on the rump) to sweep away the tracks. But, of course, this does not erase the traces of the sweeping which are even clearer and easier to follow (this tactic would be used by Hausa thieves, but it does not seem widespread and especially provides the Tuaregs with an opportunity to make fun of them ${ }^{15}$ ).

Cattle thieves are not the only ones being pursued by their tracks. All thieves are, even those who commit petty theft in village shops. Any marauder who seeks to thwart these future pursuers must be patient. He can spend a day observing the life of the village. He then notices the most worn model of sandals (Fig. 19.4), buys them discreetly and puts them on just before committing his crime. This will make it more difficult to find him afterwards. Others go so far as to change pairs of sandals several times during their escape. In the past, rudimentary sandals were specially made to

\footnotetext{
${ }^{15}$ This practice is nevertheless attested elsewhere in the Sahara, notably in Algeria in the Tabelbala oasis studied by Champault (1969). It is also mentioned that one manifests one's identity by leaving a clearly visible footprint, for example, near luggage that one must leave unattended for a while. It is also possible to place things within a circle drawn with the foot, which reminds us of the Tubus ortozze.
} 
Fig. 19.4 Trackways formed by two dromedaries and a dromedary driver (erg Chebbi, Merzouga, Morocco). The dromedary driver walks forward by pulling on the lead animal's lanyard. (Photo L. Gagnol 2014)

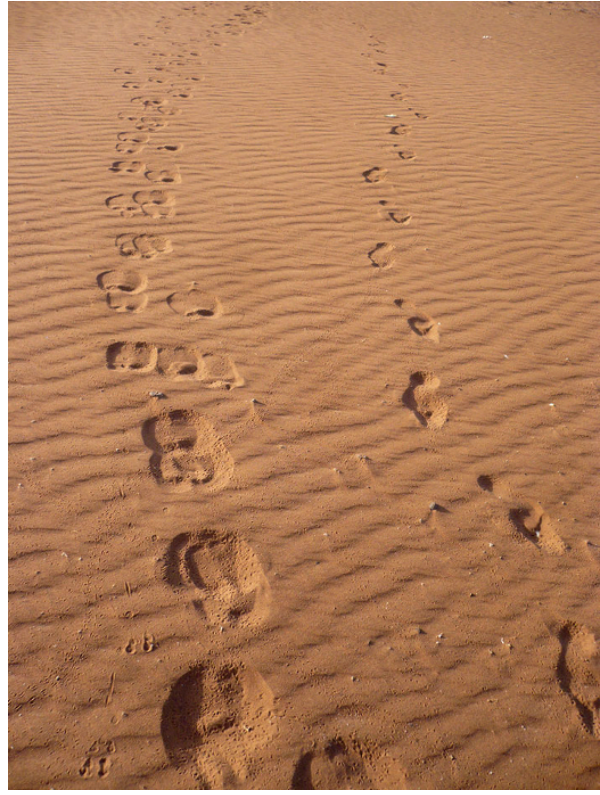

commit a crime, ${ }^{16}$ or even, in Hermès' style, were made in such a way that the heel was at the front and inversely the tip at the back, to reverse the direction of the track: this stratagem making it possible to deceive pursuers who were misled and followed the trackway in the wrong direction. ${ }^{17}$

Nevertheless, there are counter-strategies to overcome the tricks of thieves. There is the anecdote of the commercial marauder whose victims had to walk around the village to recognize the path the thief took after his theft and compare these tracks with those that entered the village to be sure that they corresponded to the same individual. Tracking specialists know how to identify a footprint even if the person has changed shoes several times during the escape. The simplest way to fault the thieves' trickery is not to follow the tracks from where the theft was committed or to try to follow the tracks which he may have blurred. The trick is to find the route by which the thief came and which therefore indicates his way to the outward journey and not the return. Indeed, in general, thieves are less attentive to their tracks when they enter the village. The objective is then to follow the trail back to the thief's home - or starting point - but make sure he or she has not been to another village. If he was able to get rid of or resell the object of his crime, his footprint has the value of legal evidence, and he has no other means than to confess. This was also observed by C. Battalion (1963: 38) at Souf in the Algerian Sahara. In Fada, a small

\footnotetext{
${ }^{16}$ On this subject, see the observations at Tabelbala de Champault (1969: 210-211).

${ }^{17}$ It is by no means a ploy specific to the Greek gods and Saharans: poachers of the French forests of yesteryear made inverted hooves for the same reasons.
} 
administrative and military town in the Ennedi, no theft from a business is said to have taken place that could not be solved, thanks to the tracks.

\section{Monitor by Tracks}

The examination of tracks makes it possible to search for an animal or a thief, but also to carry out internal surveillance of the social group within the camp or the village. This question is more difficult to investigate than theft which is often attributed to foreigners.

The Arab geographer Al-Bakri (1975: 81) tells about how in his time in the sixteenth century the inhabitants of Zawila, in present-day Libya, monitored their city. Before nightfall, one of the guards was in charge of walking around the city walls, mounted on a beast of burden to which date palm branches had been attached, dragging partly over the ground. The next morning, the footprints left overnight on the previously swept floor were carefully examined by the guard and some other people on racing camels. If they noticed suspicious footprints leaving the city, they immediately went after the thief or fugitive slave (since the city was a large slave market). This allowed the city authorities to know who was entering (and where they came from) and who was leaving the city (and the direction taken by a possible runaway). Nowadays, in the south and west of the island of Madagascar, there is

\footnotetext{
a customary system of village alliances and territorial surveillance to combat theft by detecting animal movements. Each village is responsible for its own territory which is based on the control of tracks left on the ground by zebus in strategic places of passage that are daily monitored and swept. (Saint-Sauveur, cited in Landais 2000: 458, translation TLE)
}

Nothing like this seems to be happening in the Sahara today. There are no local collective bodies responsible for carrying out such monitoring, and there is no mention of sweeping the sand to control access to a place. Although it is difficult to obtain information on this issue of internal monitoring, the attention paid to tracks seems trivial, if not almost instinctive for some people. On a daily basis, pastoralism requires sustained attention to the tracks of one's animals. Going in search of his dromedaries is an integral part of the life of a herder: they are left to wander, and it is sometimes necessary to follow their tracks for tens of kilometres to find them (often at a well or on good pastures). In villages and oases, it is also a daily exercise. A part of local life is found on the sand, and it contains many short stories for those who can read. For example, people know if a particular owner has entered his garden or left his house. One wonders what the two people who met said to each other because their tracks converged, etc. When the tracks are singular, reflecting an intriguing situation, they are examined more carefully: for example, why such a person ran, why he rested here, etc.

When a stranger enters a village, identification is carried out in three ways: by his name and genealogy when talking about him, by his face when seeing him and also 
by his imprints. Some people, before greeting a newcomer, look at the track even before they look at the face. In the village, only tracking specialists know everyone's footprints thoroughly. They then very quickly know the arrival of a stranger because new tracks appear. Foreigners are easily spotted ${ }^{18}$, and one can know each of their movements.

Near the village of Tajaé in Niger, there is a hamlet of freed ighawellan slaves who looked after their former master's cattle. They are recognized as specialists, so they are often called upon in difficult cases, such as theft. Since they know the tracks of everyone in the surrounding villages and when a robbery cannot be solved, there is a high probability, it is said, that it is one of their own and that they refuse to unveil it so as not to betray anyone.

However, there is a practice among Saharans that may require more attention. It is a commonly accepted but hidden activity of a nightly gallant visit by a young man to a young girl. To avoid being spotted, he dresses in clothes and especially sandals that he has borrowed or reserved for this purpose. He enters, preferably on cool, moonless nights, camps or premises, slipping into the tent where the girl is lying, taking care not to wake anyone and leave before the first light of day. Despite all these precautions, the footprints easily betray the night incursion. ${ }^{19}$ People in the camp/village can see tracks in the morning and go back to their source. But except in rare cases this is not done. There is a tacit tolerance of this practice, especially when people are acquainted with the person and their family and know their good intentions.

\section{The Effects of Sedentarization: Tracks in a World That Closes, Freezes and Fixes Itself}

\section{Tracks in Hunting Practice}

As we have seen, among inhabitants of the Sahara, the reading of tracks is above all a pastoral skill rather than being related to hunting. The difference between the two is

\footnotetext{
${ }^{18}$ The first European observations on the "sagacity to recognize the tracks" of desert inhabitants seem to have been made by the Swiss explorer Burckhardt (1829) who travelled to the Arabian Peninsula in the early nineteenth century. Burckhardt delivers several pages in his account of what he considers to be "prodigious" knowledge that is almost "supernatural". He mentions specific examples: the Bedouins, Burckhardt tells us, forbid foreigners who sometimes accompany them in their caravans to walk beside their horses, because their boots, shoes or sandals, unusual in these countries, would risk betraying them and attracting the curiosity of looters.

${ }^{19}$ A ploy of the Tubu girls is indicated by Chapelle (1982: 295): joining the middle of the company where the man is whom she will wait for at night, she pretends to burn her feet on the hot sand and returns to her tent, having taken care to borrow his sandals and to make several comings and goings. She thus creates "a whole path of traces. This procedure will hardly deceive anyone but it will allow her to defend herself if she is accused: "These traces, I made them, everyone has seen it"' [translation TLE].
} 
essentially in that the hunter does not know the game he is hunting intimately, unlike the herder who is looking for his animal. The latter knows the particularities of each animal he owns: its anatomy, its character and its tastes. Even if long stalks make it possible to understand the animal's personality, the hunter interprets more a generic behaviour of the species than an individual one. In order to locate a track, he then uses much more of the species' territorialized habits as well as the specific clues it leaves behind to follow it (a game path, a broken branch, a lair, etc.).

If we take the case of Tajaé, there are no more large game animals in the region. The wooded steppe has been cleared to make way for millet fields, and today pastoralists are finding it increasingly difficult to find grazing areas for their herds. Gazelles and antelopes have been decimated by the use of guns and motorcycles to hunt them. The Tuaregs no longer hunt, since they do not consume small game such as lizards (varanidae), hares, hedgehogs, partridges, jerboas, etc. Only the Hausa continue to track these animals, and for some they are specialists in tracking. For example, they know the direction a snake takes with its traces: it suffices to look at the side where the sand is deposited to know its direction. When it passes over a twig, it moves up by lateral undulation on the opposite side of the direction it is moving.

Tracks of wild animals are also observed to get rid of harmful and especially poisonous species. Some people are familiar with the tracks of wild animals that frequent the surrounding areas mainly at night. In the morning, the herders recognize the snakes or jackals (Fig. 19.5) of which they are used to crossing the track, to such an extent that they know when a foreign snake or jackal has just arrived for the first time in the area. Dangerous snakes, especially horned vipers, are pursued into their

Fig. 19.5 Footprints of a jackal (Ennedi, Tchad). This probably nocturnal track was blunted by the action of the wind on the sandy soil. (Photo. L. Gagnol 2013)

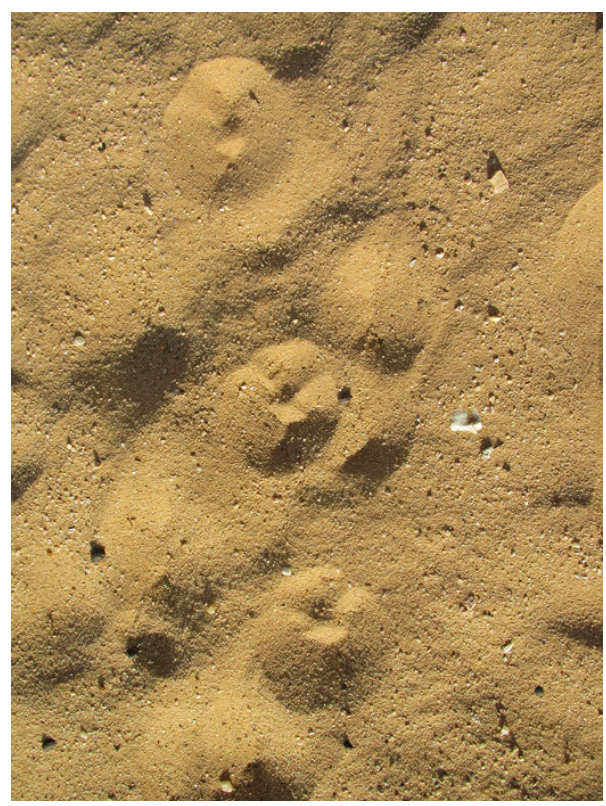


holes to kill them. It is said that a marabout (a Muslim leader and teacher) from the village of Tajaé saw tracks of vipers around him when he woke up: he followed the trail for several kilometres before flushing it out. But he didn't kill it because it didn't bite him in his sleep. He bewitched it to send it to other places. Wild animals are thus considered as the livestock of geniuses. In the Aïr, a hunter tracking a sheep in a place without water points was surprised to find traces of water drops in its prints. This was confirmed when it was flushed out: its whole chest was wet because it carried water bags for geniuses, like donkeys do for men.

\section{The Increased Difficulties of "Trace" Tracking in a Sedentary World}

The presence of roads, villages and motor vehicles makes it increasingly difficult to follow tracks, and its effectiveness tends to decrease (Fig. 19.6). But despite the sedentarization, the know-how on tracks is perpetuated, even if the knowledge seems to be declining among the younger generations, or at least moving towards those of other frame tracks. Thus young people can read the track of a motorcycle (or a $4 \times 4$ vehicle): they can identify the direction it has taken and even distinguish it from other vehicles, thanks to its tire track, its wear and tear, its inflation level and assembling marks (patch, tape). They can also recognize a biker by ear. Not by the noise as such, but by what the noise reflects of the way of driving and in particular

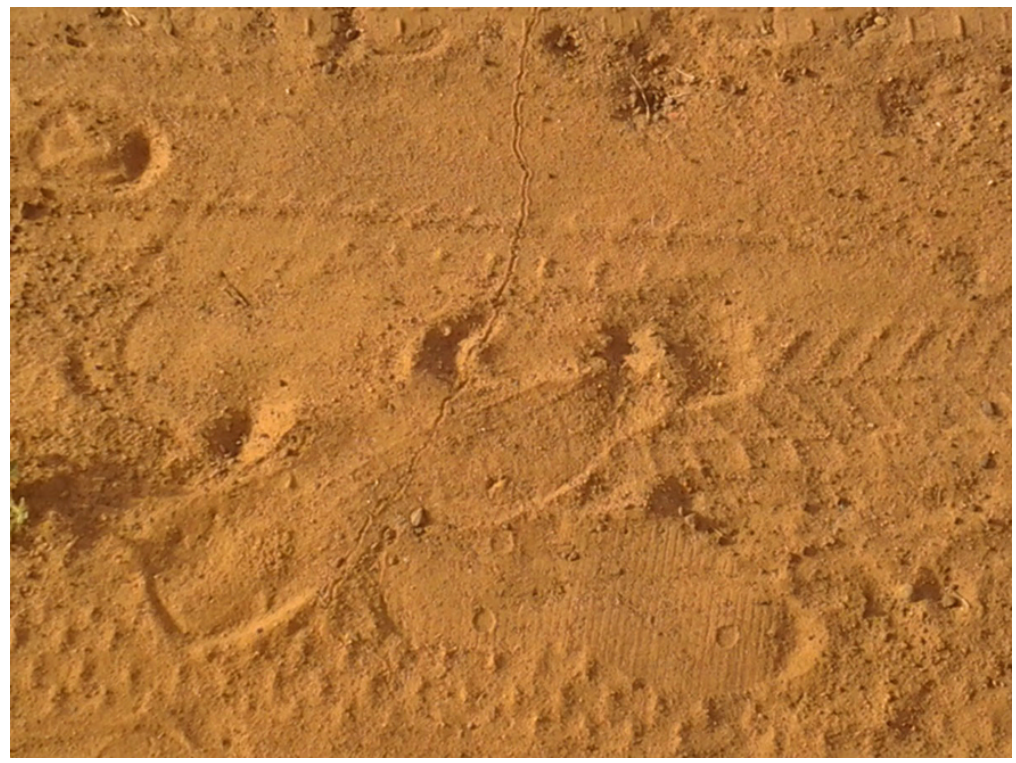

Fig. 19.6 Tracks of a human, an insect, a donkey and a vehicle on a track (Tajaé, Niger). The superposition of tracks allows to locate in time the various circulations that took place here. (Photo L. Gagnol 2012) 
the way of accelerating. The material and auditory traces reflect the driver's actions and the way he uses his vehicle.

Auditory traces are therefore also part of people's identification: if we recognize someone by their behaviour, people also identify a woman by the way she pounds, the rhythm and sound of the pestle in the mortar. An anecdote is revealing on this subject: a man walking down a street in the city of Agadez recognized a tailor friend without even seeing him - since he was sitting in a hallway - just by the sound of his scissors, in his particular way of cutting the fabric.

Today, it is the gravel roads and even more so the paved roads that make it even more difficult to apply know-how on the tracks. It obviously seems impossible to track a thief walking on tar with a stolen animal. However, some have managed to do so by observing the sand on the roadside. Knowing the direction, it is then advisable to walk along the road, paying attention to where the thieves left it. If they are in a vehicle, it gets more complicated. It is then necessary to visit the villages and especially the markets in the surrounding area to make sure that they have not sold the animals. When their tracks enter a village, it is essential to look around to make sure they have not left. Victims of theft then seek to negotiate with them through customary and/or administrative authorities. The surroundings of the village are guarded, especially at night, in order to prohibit any discreet departure with animals (on foot or in vehicles). It happened that this kind of siege lasted for more than a week, before the negotiations were successful and the pastoralists recovered their stolen animals. But in Chad and Nigeria in particular, the use of violence is widespread, and pastoralists are often armed to protect themselves against theft.

In the Sahara, people, domestic and wild animals and the landscape itself are particularly mobile. Sand in particular, by its soft nature, has the particularity of moving and constituting a moving morphology that temporarily records the movement of humans and animals by freezing it.

This work focused on the tracks as an object of knowledge and power particularly developed among Saharo-Sahelian pastoralists. Combining inspection of footprints to identify an individual in question, tracking and interpretation of the itinerary to track and find him, all this know-how on footprints is part of a hodological conception of space which, above all, is linear and in movement. To this sense of space that has often struck sedentary observers, the search for other associated clues is combined to better discern the context and understand the individual's actions. The interpretation of these clues concerns not only behaviour but also the stratagems it denotes: the reading of tracks requires anatomical and ethological knowledge but also a certain ability to take the point of view of others (of the animal, the thief, etc.).

The identification and tracking of spoor requires a thorough and proven knowledge of the desert environment. It testifies both to the relationship of humans to their territory and to domestic or wild animals, as well as to the power structures of people among themselves. The deciphering of what lies in the sand represents an unsuspected potential for knowledge and monitoring. This shows apparent links between the nomadic reading of tracks and the traceability procedures for bodies and objects, which also include monitoring their movement. However, there is an important difference: if the digital traces of computerized networks are achievable 
and therefore stable, fixed, even immutable, the tracks in the sand are only fleeting and fragile.

Acknowledgements This work would not have been possible without the active collaboration of Abdoulkader Afane, a native of this village who wrote a thesis on the ecological and pastoral knowledge of the Tuaregs. This article is also based on regular exchanges with Coralie Mounet, who works on the theme of traces based on naturalist and cynegetic know-how. Translation from French to English with DeepL and reworked by AP and TLE.

\section{References}

Al-Bakri (1975) [1068]. Description de l'Afrique septentrionale. In J. Cuoq (Ed.), Recueil des sources arabes concernant l'Afrique occidentale duvIII auxve siècles (pp. 80-109). Paris: CNRS.

Aporta, C. (2004). Routes, trails and tracks: Trail breaking among the Inuit of Igloolik. Etudes/Inuit/ Studies, 28(2), 9-38.

Bataillon, C. (Ed.). (1963). Nomades et nomadisme au Sahara. Paris: Unesco.

Bellin, P. (1963). L'enfant saharien à travers ses jeux. Journal de la Société des Africanistes, 33(1), 47-104.

Bernus, E. (1981). Points cardinaux: les critères de désignation chez les nomades touaregs et maures. Bulletin des études africaines de l'INALCO, I-2, 101-106.

Bernus, E. (1995). Perception du temps et de l'espace par les Touaregs nomades sahéliens. In P. Claval \& Singaravelou (Eds.), Ethnogéographies (pp. 41-50). Paris: L'Harmattan.

Besse, J.-M. (2004). Quatre notes conjointes sur l'introduction de l'hodologie dans la pensée contemporaine. Les carnets du paysage, 11, 26-33.

Burckhardt, J. -L. (1829). Travels in Arabia. III. London: H. Colburn.

Cabalion, S. (2013). Le système domesticatoire touareg (Tagaraygarayt, Niger). PhD thesis. In École des Hautes Ėtudes en Sciences Sociales. Paris.

Casajus, D. (1988). Jeux touaregs de la région d'Agadez. Journal des Africanistes, 58-1, 23-49.

Casajus, D. (2010). À propos d'une géométrie vernaculaire: pratiques d'orientation en pays touareg. Afriques, 02, 2010. http://afriques.revues.org/723. Accessed 21 Jan 2020.

Champault, F. D. (1969). Une oasis du Sahara Nord Occidental: Tabelbala. Paris: CNRS.

Chapelle, J. (1982). Nomades noirs du Sahara. Les Toubous. Paris: L'Harmattan.

Gagnol, L. (2009). Pour une géographie nomade. Perspectives anthropogéographiques à partir de l'expérience des Touaregs Kel Ewey (Ä̈r - Niger). PhD thesis, Université J. Grenoble I: Fourier.

Gagnol, L., Mounet, C., \& Arpin, I. (2018). De la piste animale aux lignes de désir urbaines. Une approche géoichnologique de la trace. L'information géographique, 82(2), 11-38.

Ginzburg, C. (1980). Morelli, Freud and Sherlock Holmes: Clues and Scientific Method. History Workshop Journal, 9/1, 5-36.

Ginzburg, C. (1989). Clues, myths, and the Historical Method. Baltimore: The Johns Hopkins University Press.

Ingold, T. (2004). Culture on the ground: The world perceived through the feet. Journal of Material Culture, 9-3, 315-340.

Ingold, T. (2007). Lines. A Brief History. London-New York: Routledge

Janni, P. (1984). La mappa e il periplo: cartographia antica e spazio odologico. Rome: Bretschneider.

Landais, E. (2000). Le marquage du bétail dans les systèmes pastoraux traditionnels. Revue d'élevage et de médecine vétérinaire des pays tropicaux, 53-4, 349-363.

Le Cœur, C. (1950). Dictionnaire ethnographique Téda. Paris: Larose. 
Lévy-Bruhl, L. (1927). L'âme primitive. Paris: Presses universitaires de France.

Liebenberg, L. (1990). The art of tracking: The origin of science. Claremont: David Philip.

Therrien, M. (1990). Traces sur la neige, signes sur le papier. Significations de l'empreinte chez les Inuits Nunavimmiut (Arctique québécois). Journal de la société des américanistes, LXXVI, $33-53$.

Open Access This chapter is licensed under the terms of the Creative Commons Attribution 4.0 International License (http://creativecommons.org/licenses/by/4.0/), which permits use, sharing, adaptation, distribution and reproduction in any medium or format, as long as you give appropriate credit to the original author(s) and the source, provide a link to the Creative Commons license and indicate if changes were made.

The images or other third party material in this chapter are included in the chapter's Creative Commons license, unless indicated otherwise in a credit line to the material. If material is not included in the chapter's Creative Commons license and your intended use is not permitted by statutory regulation or exceeds the permitted use, you will need to obtain permission directly from the copyright holder. 